\title{
POR UMA FORMAÇÃO ÉTICA E ESTÉTICA DE MULHERES-PROFESSORAS A PARTIR DO CONCEITO DE ALTERIDADE PERANTE A DIFERENÇA
}

\author{
Margareth Diniz \\ Universidade Federal de Ouro Preto - UFOP
}

\begin{abstract}
Resumo
O presente artigo problematiza a formação docente em relação à subjetividade, à alteridade e à diferença, especialmente relacionada às pessoas com deficiência e às políticas inclusivas. Ao abordar a trajetória das pessoas com deficiência e as concepções segregadoras que as marcaram ao longo de décadas, destaco a formação docente para a inclusão considerando o tripé, buscando dispositivos que o alcancem e rompam com modelos standards que invisibilizam e segregam o sujeito. O referencial teórico acerca da relação com o saber cunhada por Bernard Charlot atravessa o trabalho, concebendo o sujeito em relação consigo mesmo, com o mundo e com os outros, mediados pela cultura e pela linguagem, incidindo em mobilizações que perpassam a formação docente. A Conversação, introduzida pela Psicanálise, utilizada aqui como metodologia de pesquisa, possibilita às mulheres-professoras a invenção de novas saídas para lidar com o malestar, somada às visitas aos museus brasileiros, constituindo-se, assim, em dispositivos de intervenção. $\mathrm{O}$ resultado desse trabalho visa à constituição de uma experiência singular, promovendo efeitos de deslocamento físico e psíquico em mulheres-professoras em relação à arte e à cultura no projeto intitulado formação ética e estética de mulheres-professoras em uma experiência de alteridade.
\end{abstract}

Palavras-chave: formação docente, diferença, alteridade, inclusão.

\begin{abstract}
This article discusses teacher education in relation to subjectivity, alterity and difference, especially related to people with disabilities and inclusive policies. In adressing the trajectory of people with disabilities and the segregating concepts that have marked them for decades, I highlight the teacher training for inclusion considering the tripod, looking for devices that reach and break with standard models that make the subject invisible and segregate, The theoretical framework about the relationship with knowledge coined by Bernard Charlot runs through the work, conceiving the subject in relation to himself, with the world and with others, mediated by culture and language, focusing on mobilizations that permeate teacher training. Conversation, introduced by Psychoanalysis, used here as a research methodology, allows women-teacher to invente new ways to deal with malaise, in addition to visits to Brazilian museums, thus constituting intervention devices. The result of this work aims at the constitution of a singular experience, promoting effects of physical and psychic displacement in women teachers in relation to art and culture in the project entitled ethical and aesthetic training of women teachers in an experience of otherness.
\end{abstract}

Keywords: teacher training, difference, alterity, inclusion. 


\section{Introdução: do que falamos quando nos referimos à inclusão?}

Na educação, após a Segunda Guerra Mundial, podemos observar a passagem dos estudos sobre normalidade e desvio para uma abordagem sobre a diversidade e a diferença numa perspectiva social. Associada ao declínio dos modelos biológicos de compreensão de identidades sociais, e dos ideais de raça pura e perfeita como projeto de nação, bem como o questionamento sobre o racismo e outras formas de manutenção das desigualdades históricas, surgiu a possibilidade de desenvolvimento de um novo paradigma de compreensão da diversidade social em seus aspectos étnico-raciais, de condições físicas e mentais, culturais e da sexualidade, impulsionados, por sua vez, pelos movimentos sociais, como o feminismo, a antipsiquiatria e o movimento de afirmação negra, bem como o movimento das pessoas com deficiência, que será abordado aqui.

Segundo Mantoan (2003) e Mazzotta (2005), a história da educação de pessoas com deficiência no Brasil está dividida entre três grandes momentos. São eles: de 1854 a 1956, marcado por iniciativas de caráter privado; de 1957 a 1993, definido por ações oficiais de âmbito nacional; de 1993 até os dias atuais, caracterizado por movimentos a favor da inclusão escolar.

No primeiro período (1854 a 1956), as primeiras ações de educação de pessoas com deficiência ocorreram com a criação de dois importantes institutos, ambos no Rio de Janeiro: o Imperial Instituto dos Meninos Cegos, em 1854, atual Instituto Benjamin Constant (IBC), e o Instituto dos Surdos Mudos, em 1856, atual Instituto Nacional de Educação dos Surdos (INES). No ano de 1932, a educadora Helena Antipoff constituía a Sociedade Pestalozzi de Belo Horizonte, cujo objetivo era cuidar das crianças e adolescentes com deficiência, principalmente daqueles que possuíam problemas de saúde mental. Foi criado em 1954 o movimento das associações de pais e amigos dos excepcionais - APAE, prestando serviços de educação, saúde e assistência social a quem deles necessitassem (Mazzota, 2005).

No segundo período (de 1957 a 1993), a educação das pessoas com deficiência foi assumida pelo poder público, com a criação de "Campanhas" destinadas a cada uma das deficiências, como a Campanha para a Educação do Surdo Brasileiro - CESB. Em 1973, foi constituído pelo Ministério da Educação e Cultura o Centro Nacional de Educação Especial - CENESP, responsável pela gerência da educação especial no Brasil, que, sob a égide integracionista, incentivou ações educacionais voltadas às pessoas com deficiência e às pessoas com superdotação, mas ainda caracterizadas por campanhas assistenciais e iniciativas isoladas do Estado (MEC/SEESP, 2008). Nesse período as pessoas com deficiência ganharam atendimento oficial em nível nacional. (Mazzotta, 2005).

Em 1980, ainda baseada no modelo médico, a concepção de que a deficiência deveria ser "corrigida" ganha força. Por outro lado, a luta das pessoas com deficiência visa alterar essa concepção e defender que os "ajustamentos" à sociedade não deveriam ser dos sujeitos com deficiência, mas da própria sociedade. Os primeiros acadêmicos e ativistas da deficiência interrogam a complexidade que existe no conceito de deficiência, o qual, longe 
de ser sinônimo de um corpo com lesão, também denuncia a estrutura social que oprime a pessoa que possui um corpo "diferente". Em contraposição ao modelo médico, emerge o modelo social da deficiência.

O modelo social nos mostra que o corpo "diferente" não precisa ter como destino a exclusão, e sim que essa experiência singular pode ser caracterizada de diferentes maneiras. Durante esse período, a discussão sobre deficiência ganhou destaque, surgindo diversas formas de intervir sobre ela, tanto no que diz respeito à sua institucionalização como também no ensino da pessoa com deficiência.

Em 1990, o Brasil, como signatário da Declaração Mundial sobre Educação para Todos (Tailândia), passou a responsabilizar-se por assegurar a universalização do direito à Educação e desse compromisso decorreu a elaboração do Plano Decenal de Educação para Todos, concluído em 1993, com objetivo de assegurar a todos/as os/as brasileiros/as, até o final de sua vigência, "conteúdos mínimos de aprendizagem que atendam necessidades elementares da vida" (Brasil, 1990, p. 13).

Ao longo de todo o século XX, as estatísticas brasileiras foram apontando o aumento do atendimento educacional às pessoas com deficiência no país, tanto no que se refere ao número de alunos matriculados quanto ao tempo de escolarização. Sobre as características dessa população, o conceito de necessidades educacionais especiais, adotado no país até a divulgação da Política Nacional de Educação Especial na perspectiva da educação inclusiva, em 2008, ainda apresentava um olhar pouco nítido sobre o aluno da educação especial. A utilização desse conceito, embora tivesse como intenção declarada ressaltar a necessidade de adaptação dos processos educativos a qualquer sujeito (que apresentasse dificuldades por tempo limitado ou não), muitas vezes colaborou para a continuidade da patologização de parcela da população, especialmente das camadas mais pobres, como foi frequente na história da educação brasileira.

Segundo dados do censo demográfico de 2010, divulgado pelo Instituto Brasileiro de Geografia e Estatística (IBGE), mais de 45,6 milhões de brasileiros declararam ter alguma deficiência. O número equivale a $23,9 \%$ da população do país. A deficiência visual é a que possui o índice mais elevado, 35,7 milhões de pessoas, segundo os dados. Pelo estudo, 18,8\% dos entrevistados declaram ter dificuldade para enxergar, mesmo com óculos ou lentes de contato. Dados do Censo Escolar de 2015 indicam um crescimento significativo em relação às matrículas de alunos com deficiência na educação básica. Estatísticas apontam que no ano de 2014, 698.768 estudantes com deficiência estavam matriculados em classes comuns (Brasil, 2015). Outro dado significativo fornecido pelo Ministério da Educação (MEC) foi sobre o aumento de $198 \%$ no número de professores com formação em educação especial. Em 2003, eram 3.691 docentes com esse tipo de especialização. Em 2014, esse número chegou a 97.459 (Brasil, 2015).

As políticas inclusivas constituem-se como resultado de muitas discussões, estudos teóricos e práticas que tiveram a participação e o apoio de organizações de pessoas com deficiência e educadores/as, no Brasil e no mundo, além de um contexto histórico favorável em que se resgata a Educação como lugar do exercício da cidadania e da garantia de direitos, sistematizada na Declaração Universal dos Direitos Humanos (1948), a qual 
defende uma sociedade mais justa, combatendo qualquer forma de discriminação. Nessa esteira, as escolas estavam ferindo esses direitos, tendo em vista os altos índices de exclusão escolar das populações mais pobres, das pessoas com deficiência, dentre outros, que estavam sendo, cada vez mais, marginalizadas do processo educacional (Diniz, 2012) ${ }^{1}$.

Hoje, muitos alunos com deficiências, transtornos globais do desenvolvimento e altas habilidades/superdotação estão matriculados em classes comuns de escolas públicas em todo território nacional, o que significa uma mudança de perspectiva em relação a essa população: da crença anterior de que o atendimento apropriado deveria ocorrer em locais específicos, separadamente da população em geral, à matrícula obrigatória desses/as alunos/as em escolas comuns públicas.

O princípio fundamental da educação inclusiva consiste em que todas as crianças devem aprender juntas, não importando quais dificuldades ou diferenças elas possam ter. Nessa perspectiva, o sistema educacional se aproxima da ideia de um caleidoscópio (Mantoan, 2003), ou seja, de uma imagem que contém a capacidade de se formar como única e, ao mesmo tempo, ser diversa, dada a grande riqueza de suas partes.

A inclusão demanda que os recursos escolares para atender os/as alunos/as estejam na escola, ao alcance do/a professor/a e não ofertados à parte, exigindo a adequação do espaço físico da escola, dos seus princípios e concepções de ensino e de aprendizagem, bem como da avaliação escolar, ao mesmo tempo em que deve investir na formação docente.

A inserção escolar da criança com deficiência, iniciada desde a Educação Infantil no sistema comum de ensino, constitui uma possibilidade de que elas tenham uma trajetória educacional mais favorável para suas aprendizagens, na medida em que partilham de um ambiente comum, marcado pelo princípio da inserção de todos e não pela ideia do alguns; onde vivem a possibilidade de conhecer formas de estar no mundo, diferenciadas da sua, e de aprender, podendo experimentar situações de aprendizagem mais ricas para si mesmas e para as possibilidades de intervenção pedagógica. O que podemos nos perguntar é se todos os sujeitos se beneficiariam do que a escolarização (letramento/matematização, dentre outros) pode oferecer às pessoas com deficiência, e, nesse caso, concluirmos que para alguns sujeitos, dada a radicalidade da deficiência e/ou necessidade específica, não há benefícios, o que nos coloca, por sua vez, a demanda de pensar na constituição de outros aparatos públicos que garantam o direito à socialização e à preparação dos/as cidadãos(ãs) para a democracia e quiçá para o mercado de trabalho.

Essa demanda da inclusão com certeza interroga o lugar da docência. As responsabilidades e exigências profissionais passam a ser registradas nos documentos legais, desencadeando-se um processo necessário de transformação da docência em que os/as professores/as se depararam com a necessidade de renovar os saberes, bem como suas atitudes e seus valores, suas habilidades, conceitos e práticas pedagógicas construídas durante a trajetória formativa inicial e no cotidiano educativo. Os/as professores/as experimentam situações complexas e diversas às quais se impõe uma nova ordem como condição para a docência, interferindo no processo de trabalho e em sua disposição, provocando uma situação desconfortável quanto ao seu novo lugar diante da sociedade, dos/as alunos/as, do saber, bem como seus modos de fazer e de ser. 


\section{O "tipo ideal" docente e o "apagamento" do sujeito-professor/a}

É certo que as reformas instruídas pela LDB 9394/96 (Brasil, 1996) direcionaram a política educativa brasileira, reconfigurando o projeto nacional e exigindo também uma nova docência. Segundo Campos (2003), os termos eficiência e eficácia passaram a fazer parte do vocabulário referente à qualidade docente, deixando de lado a concepção de professor reflexivo, que dominava até então. A ideia de professor competente passou a ser o foco da formação. Afirmam Evangelista e Shiroma (2004, p. 61) a presença, nos documentos oficiais das reformas da década de 1990, de slogans como "profissionalização", "competência", "excelência", "qualidade", "mérito" e "produtividade", os quais imprimiram características e significados valorativos de racionalidade técnica no trabalho docente e no perfil daquele/a que exerce a atividade.

Neste contexto de mudança, os cursos e programas destinados aos professores/as em atividade na docência, a chamada formação continuada, permanente ou em serviço (vocabulário com diferentes concepções), são apontados como locus de promoção de mudanças profissionais, cujo objetivo é fazer com que o/a docente aprenda a nova ordem professoral, por meio de espaços planejados, com a intenção de mudar a mentalidade docente através da aprendizagem de conhecimentos e atitudes para, dessa maneira, transformar a prática. A construção do "tipo ideal" docente pode ser constatada nas análises dos textos dos documentos que fundamentam a docência, profundamente influenciados pelas orientações de organismos internacionais patrocinadores, como Organização dos Estados Americanos - OEA, Unesco, Unicef, Bird, Banco Mundial - BM (Evangelista; Shiroma, 2004). O perfil docente aponta um profissional-gestor que seja capaz de administrar a sua formação, esteja atento aos pacotes educacionais e seja eficaz na execução de tarefas. A formação continuada na concepção de treinamento instala um processo de desapropriação dos recursos que imprimem autonomia aos/às professores(as): a capacidade de teorizar, de planejar e de avaliar.

Como propõem as Diretrizes Curriculares Nacionais para o Curso de Graduação em Pedagogia, Resolução CNE/CP n. 1/2006 (Brasil, 2006), o egresso do Curso de Pedagogia deverá estar apto a lidar com as diferenças. Tal proposição deve ser ampliada para a formação de todos/as os/a professores/as. Entretanto, podemos nos perguntar: é possível formar previamente o/a professor/a para dar conta do amplo espectro das diferenças que constituem a vida? É possível prever o impacto que nos causará subjetivamente a relação com cada diferença?

Se considerarmos a complexidade da vida e da escola, a partir de uma visão de sujeito incompleto, ou inacabado, como pressupõe Freire (2002), nunca estaremos aptos e não saberemos o que nos aguarda nas relações com as diferenças. $\mathrm{O}$ que propomos é sairmos do lugar do saber e do poder sobre o outro e nos abrirmos para o encontro com o outro (Ferre, 2001; Larrosa, 1998). Skliar (2006) afirma que não se trata de formarmos professores/as que possuam um discurso racional acerca do outro e sua diferença. 
Para tal experiência, o conceito de alteridade enquanto reconhecer-se no outro, mesmo que a princípio existam diferenças físicas, psíquicas e culturais, é fundamental para se pensar a formação docente. A busca pela inserção da alteridade como objetivo educacional, que presume uma convivência democrática e igualitária entre diferentes grupos, recebeu denominações plurais também nas diferentes partes do globo, tais como: no mundo anglosaxão - educação multicultural; na Europa - pedagogia do acolhimento, educação para a diversidade, educação intercultural (Fleuri, 2003a). Segundo informa Fleuri (2003b), a educação intercultural, atualmente, na América Latina, vem recebendo diversas denominações, variando de país para país, tais como: etno-educação (Colômbia), educação bilíngue (Bolívia), educação intercultural bilíngue (Guatemala e Brasil).

O princípio da alteridade consiste na relação conectada entre unidade e multiplicidade, sem que se exclua um dos polos. O reconhecimento da alteridade, das características do outro (social, étnica, política, religiosa etc.) implica em um sistema educativo para a compreensão de sujeitos dissonantes, surgindo a consolidação do diálogo, de acordo com Marques (2006).

O corpo docente e os/as educandos/as vivenciam esse microuniverso de relações plurais e discriminatórias sem, contudo, buscar o entendimento da alteridade em um âmbito maior, ou seja, o âmbito dos mecanismos que geram a dialética da exclusão/assimilação. Assim, novas perspectivas de compreensão das diferenças, de olhar para o outro com suas distinções, tanto aparentes, como a etnia, quanto interiorizadas, como a cultura, devem ser objeto de reflexão no campo pedagógico. Todavia, Fleuri (2006, p. 26) alerta para o perigo de uma "[...] política da diversidade" em que se produzem "[...] sujeitos da mesmice", isto é, multiplicam-se identidades a partir de sistemas prévios e estáveis, aceitando de diferente apenas pequenos fragmentos do outro.

Interessante seria preconizar na formação docente o reconhecimento do outro, ampliando a visão para o desconhecido e compreendendo que esse outro não é só um indivíduo com o qual alguém se relaciona socialmente, mas também um outro que habita em nós. A educação, pensada com base na perspectiva da alteridade, passa a ser concebida como o processo construído pela relação particular e intensa entre diferentes sujeitos, os quais possuem opções e projetos também diferenciados, de acordo com Fleuri (2006).

Como superar na educação uma visão de formação que visa o treinamento, que objetiva o ensino de maneiras de ser, de fazer, de pensar e de viver, distantes da "assunção do sujeito" (Freire, 2002, p. 25)? Para Freire (2002, p. 24), "a aprendizagem da assunção do sujeito é incompatível com o treinamento pragmático ou com o elitismo autoritário dos que se pensam donos da verdade e do saber articulado". Ao contrário, a assunção implica ruptura, decisão e novos compromissos, uma vez que ela engendra novas opções. Pressupondo assim algo do emocional. Para Freire, o treinamento impede que a construção de uma identidade seja a dialética entre o pessoal e o social, racionalizando a consciência, ao contrário do desenvolvimento da consciência crítica.

Não há como pensar a formação docente a partir das reformas educativas sem considerar a subjetividade e a alteridade, entendidas aqui como as relações do sujeito consigo mesmo e com o outro. Apesar da lacuna nas pesquisas sobre as ressonâncias da 
formação continuada pós-formação inicial, os trabalhos que se dedicam a esse tipo de estudo apontam que a eficácia dos programas e cursos ainda é um desafio. Os resultados das formações que têm o intuito de interferir na racionalidade docente, catalisando mudanças no seu modo de ser, pensar e fazer, indicam que outros fatores são envolvidos no processo de aprendizagem docente. Segundo Gatti (2007), estudos da psicologia social apontam que as mudanças pessoais e profissionais envolvem questões psicossociais. A autora registra que: “[...] os conhecimentos adquirem sentido ou não, são aceitos ou não, incorporados ou não, em função de complexos processos não apenas cognitivos, mas socioafetivos e culturais" (Gatti, 2007, p. 192), bem como aspectos inconscientes quase nunca considerados nesses processos formativos (Diniz, 2005).

Apossando-se da perspectiva descontinuísta do saber, é possível dizer que o/a professor/a na atualidade encontra-se na dinâmica da descontinuidade/continuidade da relação com o saber construído ao longo de sua trajetória profissional. Ser docente na escola inclusiva ou na educação para todos/as é estar na situação de aprender de novo e aprender que o outro é o outro. E aprender sobre a diferença é abrir mão "do ser" para arriscar-se ao "não ser" ou ao "vir a ser". E mais, o/a professor/a, antes mesmo do processo de formação que se dispõe, já se encontra diante das concepções da educação e já possui uma relação com o saber-aprender. Para Charlot (2000), a relação se dará a partir das relações já construídas:

Se a relação com o saber é uma relação social é porque os homens nascem em um mundo estruturado por relações sociais que são também relações de saber. O sujeito está imerso nessas relações de saber. Isso porque ocupa uma posição nesse mundo. Também, porque os objetos, as atividades, os lugares, as pessoas, as situações, com os quais ele se relaciona ao aprender estão, eles, igualmente inscritos em relações de saber [...] (Charlot, 2000, p. 85-86).

Bernard Charlot diferencia a "posição objetiva" e "posição subjetiva" do sujeito em seus estudos. O lugar objetivo é o lugar ocupado no social. Segundo o autor,

[...] o lugar objetivo, o que pode ser descrito de fora, pode ser reivindicado, aceito, recusado, sentido como insuportável. Pode-se também ocupar outro lugar na mente e comporta-se em referência a essa posição imaginária [...] (Charlot, 2000, p. 24).

Já o lugar subjetivo é o lugar assumido pelo sujeito. Essa diferenciação pode significar a possibilidade de adesão ou da resistência aos condicionantes concretizados nas intencionalidades e prescrições formativas e, ao mesmo tempo, permite direcionar o olhar investigativo para o/a professor/a enquanto sujeito na relação com o saber. Para Charlot (2000), o sujeito tem uma forma de interagir com o saber que pressupõe relações com o outro, com o mundo e com ele mesmo, a partir das quais constrói significados e sentidos para suas práticas e para as coisas que o cerca. Na relação com o saber os sujeitos são únicos, mas estão em interação com construções simbólicas temporais e dinâmicas que 
interferem na constituição dos sujeitos, mas são também construídas por eles/as², implicando a alteridade.

Outro pesquisador que explora a ideia dos modos de ser, de fazer e de viver numa determinada atividade é Ives Clott (2006). Para o pesquisador, toda atividade tem uma história com regras e normas implícitas que são compartilhadas entre os sujeitos: "Cada um se vê, por meio de suas próprias atividades no interior da divisão do trabalho, simultaneamente como sujeito e como objeto dessa conservação e dessa invenção [...]" (Clott, 2006, p. 81). O sujeito pode voltar-se para a "aceitação" ou "resistência" à construção do já dito "modo de ser", isto é, a disposição do sujeito está atrelada às suas necessidades e interesses, onde se envolvem os processos de mobilização do sujeito.

Charlot $(2000 ; 2005)$ trabalha com o conceito de mobilização voltado para a relação do sujeito com o saber-aprender. Entende que o sujeito tem determinadas relações com o saber em que perpassa a dimensão da mobilização para o saber-aprender. Explicando melhor, há algo que o impulsiona na busca pelo saber. Há algo que lhe faz sentido. Para Charlot (2000):

O conceito de mobilização implica a ideia de movimento. Mobilizar é por em movimento; mobilizar-se é pôr-se em movimento. Para insistir nessa dinâmica interna é que utilizamos o termo "mobilização", de preferência ao de "motivação". A mobilização implica mobilizar-se ("de dentro"), enquanto que a motivação enfatiza o fato de que se é motivado por alguém ou por algo ("de fora"). É verdade que, no fim da análise, esses conceitos convergem: poder-se-ia dizer que eu me mobilizo para alcançar um objetivo que me motiva e que sou motivado por algo que pode mobilizar-me. Mas o termo mobilização tem a vantagem de insistir sobre a dinâmica do movimento (Charlot, 2000, p. 55).

A questão que está posta no âmbito da formação docente é a dificuldade de se transmitir essa concepção: consentir e aceitar a diferença são virtudes não concebidas sem a escuta:

Se discrimino o menino ou menina pobre, a menina ou o menino negro, o menino índio, a menina rica; se discrimino a mulher, a camponesa, a operária, não posso evidentemente escutá-los e se não os escuto, não posso falar com eles, mas a eles, de cima para baixo. Sobretudo, me proíbo entendê-los. Se me sinto superior ao diferente, não importa quem seja, recuso-me escutá-lo ou escutá-la. $\mathrm{O}$ diferente não é o outro a merecer respeito é um isto ou aquilo, destratável ou desprezível (Freire, 2002, p. 136, grifos do autor).

Há uma constatação de que os currículos dos cursos de graduação, de forma geral, bem como os currículos de pós-graduação em nível de mestrado e de doutorado, não têm sido capazes de formar docentes para lidarem com o diferente em sua plenitude, visto que as reflexões iniciais são ínfimas diante de um desafio muito maior. Os discursos dos/as docentes revelam que os cursos de graduação não têm oferecido essa formação, pois 
reiteram a falta de preparação para lidar com a gama de questões inerentes à diversidade e à diferença humana. Dessa forma, a alteridade é visada na capacitação de professoras/es, elencando aspectos que poderiam abrir espaço para as discussões nos cursos de formação, possibilitando uma instrução voltada para aspectos pluriculturais. É como admitir ou recusar o outro que existe em nós. Ainda nessa mesma linha de considerações, para o exercício da cidadania e para se estabelecer uma relação pacífica e construtiva com os diferentes, a alteridade torna-se um pré-requisito.

A visão do outro é o que nos permitirá, também, compreender o mundo a partir de um olhar distinto, partindo tanto do diferente quanto de nós mesmos, movidos pela experiência do contato. Para Laplantine (2000), a alteridade é como se fosse nossa garantia de sermos antirradicais: a experiência da alteridade (e a elaboração dessa experiência) leva-nos a ver aquilo que nem teríamos conseguido imaginar, dada a nossa dificuldade em fixar nossa atenção no que nos é habitual, familiar, cotidiano e que consideramos evidente. Aos poucos, notamos que o menor dos nossos comportamentos (gestos, mímicas, posturas, reações afetivas) não tem realmente nada de natural. Começamos, então, a nos surpreender com aquilo que diz respeito a nós mesmos, a nos espiar. O conhecimento (antropológico) da nossa cultura passa inevitavelmente pelo conhecimento das outras culturas; e devemos especialmente reconhecer que somos uma cultura possível entre tantas outras, mas não a única.

\section{Subjetividade, alteridade e formação para a inclusão}

Geralmente, o que escutamos de professoras e professores em momentos de formação é que não estão preparadas/os para lidar com as especificidades que cada sujeito apresenta. Para que possamos mudar essa lógica de estarmos preparados/as como uma questão pronta e acabada, para outra lógica em que nos preparamos o tempo todo, em processo, diante de cada singularidade, será preciso considerarmos dois movimentos: um subjetivo e outro de formação. Inicialmente, cada sujeito - professor/a deverá se perguntar que posição ele/a irá assumir diante da inclusão e da diversidade. Num segundo momento deverá haver um investimento na formação que precisa romper com modelos pré-estabelecidos. A partir dessa mudança de posição, poderemos pensar num terceiro movimento mais amplo: o político, o qual poderá levar a mudanças estruturais no campo educacional.

Podemos afirmar em relação ao primeiro aspecto, o subjetivo, que a racionalidade científica é importante para os processos formativos e informativos, porém, ela não modifica por si só o imaginário e as representações coletivas negativas que se construíram sobre os ditos "diferentes" em nossa sociedade. O aspecto subjetivo está sobremaneira ligado à construção da identidade docente e a identidade não é um dado adquirido, não é uma propriedade, não é um produto. A identidade é um lugar de lutas e conflitos, é um espaço de construção de maneiras de ser e estar na vida e, consequentemente, de ser e estar na profissão docente. 
O conceito de identidade é complexo e situa-se em "várias encruzilhadas", sendo de interesse de áreas diversas, como Antropologia, Ciências Sociais, Psicologia, Psicanálise, Filosofia, que têm contribuído com algumas formulações. A nossa identidade se compõe da nossa raça/etnia, nacionalidade, sexo, idade, gênero, crenças, classe, história de vida. Tudo isso está presente na relação professor/aluno/a e entre os próprios educadores/as. Nesse sentido, a reflexão sobre a inclusão e a diversidade cultural nos conduz a um repensar da identidade do professor/a, aqui entendida como um conjunto de dispositivos que podem operar politicamente. Para além da identidade, ainda se colocam as questões singulares de cada um/a.

Nessa relação com o "outro", o que modificar? Como observar e perceber o "outro"? A partir dessa percepção, o que repensar sobre os currículos? Ou talvez novas metodologias, novas perspectivas? Como ultrapassar o individualismo que o mundo pós-moderno impõe? Considerando a necessidade de melhoramento do processo de ensino e aprendizagem, visando às constantes transformações que se operam em nossa sociedade como um todo, procuramos destacar a formação dos/as professores/as como alvo fundamental para a alteridade chegar até a práxis pedagógica. A fim de assinalar a necessidade de uma formação que incite ressignificar o professor e seu modo de anunciar a relação com o "outro", o aprofundamento da noção de alteridade surge para os educadores como necessário e inevitável para o apaziguamento e, principalmente, para o convívio com a diferença.

Cada construção linguística que fazemos, cada gesto nosso, nossos pensamentos estão perpassados por nossas escolhas, às vezes inconscientes, possibilitando diferentes e múltiplos caminhos a serem trilhados. Descobrir os motivos dessas escolhas, entendê-las, analisá-las à luz de uma reflexão colada aos processos históricos e sociais da humanidade deveria ser uma das tarefas do/a educador/a. Sobre a questão de gênero na educação, por exemplo, o que levaria um grande contingente de mulheres a se tornarem professoras? Essa escolha se situa, para muitas, como missão, como amor pelas crianças, como conciliação possível entre a vida familiar e a vida profissional e não pelo "desejo" de ensinar. O que significará este desejo de ensinar?

Essa reflexão nos levará a entender que somos múltiplos, mutáveis, imprevisíveis, fragmentados. Essa é uma discussão que precisa estar presente na escola, pois, ao nos considerarmos sujeitos, poderemos ter outro olhar para o/a nosso/a aluno/a. Uma visão e uma prática pedagógica que enxergue o outro nas suas semelhanças e diferenças não condiz com práticas discriminatórias e nem com a crença em um padrão único de comportamento, de ritmo, de aprendizagem e de experiência. A ideia de padronização dá margem ao entendimento das diferenças como desvio, patologia, anormalidade, deficiência, defasagem, desigualdade. $\mathrm{O}$ trato desigual das diferenças produz práticas intolerantes, arrogantes e autoritárias (Diniz, 2012).

Por outro lado, há outra concepção acerca da formação docente que procura ressaltar o fato de que os/as professores/as se tornam os/as professores/as que são porque retraduzem para si, a partir das suas características pessoais, os conhecimentos teóricos, as interações que vivenciam dentro e fora da escola, as observações que fazem de outras práticas 
docentes antes de se tornarem professores e professoras e no próprio contexto onde atuam. De acordo com essa perspectiva de análise, os profissionais criam, a partir de sua experiência, soluções para os problemas que eles próprios definiram como sendo relevantes. Ou seja, os professores e as professoras constroem saber, constroem conhecimentos e não apenas utilizam os conhecimentos produzidos nas instâncias consideradas responsáveis pela formação docente. Esses profissionais têm como perspectiva uma posição investigativa, de pesquisa cotidiana. Os desencaixes da formação de professores/as são estudados por muitos/as pesquisadores/as por diversas óticas, como podemos visualizar nos trabalhos que estudam a produção na área, como os de Marli André (2006), mas é fato que ainda é necessário problematizarmos a questão das relações com as diferenças em tal formação. De acordo com a pesquisadora:

Não faz falta um discurso racional sobre a surdez, por exemplo, para se relacionar com os surdos, não é necessário um dispositivo técnico acerca da deficiência mental para se relacionar com os chamados 'deficientes mentais' (André, 2006, p. 31).

De acordo com Skliar (2001), todos/as os/as alunos/as e professores/as deveriam ser alertados para o fato de estarem imersos no mundo da alteridade, criando possibilidades, durante sua formação, para uma mudança em suas representações políticas e culturais sobre os sujeitos. É importante questionar os discursos gerados nas relações com as diferenças em todos os espaços e tempos de suas vidas pessoal, acadêmica e profissional. Nas palavras do autor:

Considero que a formação de professores [...] deve ser feita na direção de uma imersão do professor e da comunidade escolar no mundo da alteridade e uma mudança radical, já apontada anteriormente, nas representações políticas e culturais sobre esses sujeitos. [...] Em função disto, não concordo que o professor deve se preparar mais uma vez, como um especialista para cada uma das deficiências, e sim que se tem que formar como um agente cultural que está alerta a não ser ele/ela mesmo/a um reprodutor inocente e ingênuo de fronteiras de exclusão/inclusão (Skliar, 2001, p. 18).

Larrosa (2002) aponta que é preciso nos lançar à experiência e nos reconhecermos nela. $\mathrm{O}$ ser ex-posto na experiência corre o risco de ser transformado por esta, buscando problematizar os discursos gerados nas suas relações com as diferenças e internalizando essas transformações. O sujeito da experiência corre o perigo de se indignar, ou seja, não se conformar com a situação posta, buscando sempre respostas às suas indagações, nunca se acomodando. Portanto, experiência não é prática, pois esta nem sempre está sensível e reflexiva ao momento vivido. Explicita o autor:

Do ponto de vista da experiência, o importante não é nem a posição (nossa maneira de pormos), nem a "o-posição" (nossa maneira de opormos), nem a 
"im-posição" (nossa maneira de impormos), nem "pro-posição" (nossa maneira de propormos), mas a "ex-posição", nossa maneira de "ex-pormos", como tudo o que isso tem de vulnerabilidade e de risco. Por isso é incapaz de experiência aquele que se põe, ou se opõe, ou se impõe, ou se propõe, mas não se "ex-põe". É incapaz de experiência aquele a quem nada lhe passa, a quem nada lhe acontece, a quem nada lhe sucede, a quem nada o toca, nada lhe chega, nada o afeta, a quem nada o ameaça, a quem nada ocorre. (Larrosa, 2002, p. 25, destaques do autor).

De que forma propiciar na formação experiências de alteridade? Como promover a exposição dos/as nossos/as alunos/as-professores/as às experiências? Hardt (2010) nos aponta que não podemos, na formação, dar o mesmo formato a sujeitos distintos, sendo a experiência única para cada um/a, devendo cada um/a assumir suas próprias possibilidades como educador e educadora. Segundo Hardt:

Para assumir tal possibilidade, por vezes é necessário "combater o que já se é", ainda que esse esforço não esteja inserido em nenhum propósito emancipador. A ideia de formação precisaria ser entendida como uma "vontade de Arte para poder mostrar sua dimensão estética ou poética". A formação tem uma relação com a invenção, com a capacidade criativa dos seres humanos, não é uma busca do autoconhecimento, da arrogância de quem se constituiu individualmente, mas tem relação com as experiências pelas quais passamos e como elas nos tocam (Hardt, 2010, p. 7-8, destaques da autora).

Compreendemos que os primeiros momentos de formação profissional devem proporcionar as bases, as ferramentas com as quais os/as docentes vão dar início ao seu modo de aprender a ensinar a todos/as os/as estudantes, independentemente das suas condições físicas e sensoriais, e, ao mesmo tempo, de solidificar a sua prática pedagógica e a experiência de ser professor/a, a partir da escuta aos seus alunos/as, da reflexão, do diálogo com o outro, na diversidade de saberes que o vai constituindo. A compreensão de como os docentes pensam, sentem e agem, quando têm em suas salas de aula sujeitos que constituem a categoria "aluno/a com deficiência", exige uma constante disposição para a formação continuada. (Marques, 2006). A singularidade das questões trazidas pelos estudantes em sua particularidade impacta sobremaneira a subjetividade docente, por vezes elucidando e evidenciando a relação saber-não-saber dos/as docentes. Assim, é importante compreender como os sujeitos são subjetivados por alguns discursos, bem como os usos que são feitos desses discursos, tanto para incluir quanto para excluir na educação básica e no Ensino Superior

O dispositivo da escrita ao longo da formação possibilita que o/a docente vá atribuindo sentidos subjetivos sobre o ser docente. É importante organizar vários momentos de formação nos quais os docentes são instigados a questionar suas concepções e a assumir eventuais preconceitos e estereótipos presentes na sua prática e na cultura escolar. A formação docente deve ter como norte a construção de concepções que valorizem as 
singularidades de todos/as os/as estudantes. A questão da formação inicial e em serviço se torna presente como ponto a ser mais bem trabalhado no interior das universidades, ao lado de questões relacionais que dizem respeito ao reconhecimento do outro e à superação das dificuldades experimentadas durante o processo educativo. O Ensino Superior tem uma importante função na formação de profissionais, seja no bacharelado, seja na licenciatura; e a forma como a questão da diferença e da deficiência, em especial, é tematizada ou não nos cursos de graduação pode conduzir a uma maior visibilidade ou silenciamento dessa questão.

Ao enfrentarem o desafio de ter em seus cursos estudantes com demandas distintas, os docentes não podem recorrer apenas aos conhecimentos formais que construíram durante os processos de formação acadêmica. É preciso, para além da formação teórica, uma abertura para viver a experiência docente em sua ampla concepção inclusiva, bem como um comprometimento e um engajamento subjetivo a fim de se colocar em posição de saber/não saber. Nóvoa já apontava a perspectiva da reflexão crítica desde o início dos anos 1990:

A formação não se constrói por acumulação de cursos ou técnicas, mas sim através de um trabalho de reflexividade crítica sobre as práticas e de reconstrução permanente de uma identidade profissional (Nóvoa, 1992, p. 25).

A partir do pensamento de Nóvoa (1992), entendemos que a formação docente para trabalhar na perspectiva inclusiva é um processo de permanente construção de sentidos subjetivos. Para Scoz, Castanho e Tacca (2012, p. 131),

[...] a questão da subjetividade vem sendo discutida com muita ênfase nas últimas décadas, quando se percebeu que diversas situações humanas vividas pela sociedade contemporânea podem ser compreendidas quando analisadas a partir da subjetividade.

Lidar com o saber-não-saber é uma perspectiva colocada pela Psicanálise na formação docente, entendendo que precisamos avançar de uma posição em que a formação está pronta e concluída para uma perspectiva em que nos formamos continuamente e no contato com a situação inédita e inesperada que se apresenta. Assim, os saberes docentes são elaborados e constantemente atualizados a partir das relações com as pessoas com deficiências, das vivências do exercício profissional, das descobertas das diversidades de aprender e de ensinar, da troca de experiências com os seus pares e, principalmente, dos resultados da escuta constante dos próprios estudantes com deficiências, em um exercício constante de alteridade.

Portanto, uma formação docente que prime pela diversidade humana deve considerar os valores, as normas, os discursos, os princípios que os sujeitos interiorizam durante suas trajetórias de vida e, também, a maneira como os exteriorizam, transformando-os em atos diante da realidade objetiva. Consideramos que a posição do sujeito no trabalho docente antecede toda e qualquer formação e preparação para o exercício da carreira profissional, associando-se à própria história de vida do/ educador/a. Sua trajetória individual o induz a 
um percurso formador e, sem dúvida, não apenas marca, como, sobretudo, determina sua vida profissional.

Embora haja uma busca por uma identidade docente, ou uma tendência em se pensar algo que seja mais ou menos único como imagem docente, o que acontece de fato é a detecção de indícios de identidades plurais, visto que os sujeitos possuem histórias diferentes, trajetórias e desejos diferentes. E os cursos de formação não têm conseguido incorporar em seus princípios a diversidade profissional e pessoal em que a educação está imersa, provocando a ilusória promessa de receitualização do processo de ensino e de aprendizagem. A formação docente é processual e deve se fazer em continuidade a partir de um itinerário de formação que considere a amplitude da educação e dos sujeitos nela envolvidos.

\section{De que forma podemos incorporar na formação docente o conceito de alteridade?}

A escola, apesar de ser um espaço onde as diferenças sempre coexistiram, nem sempre reconheceu sua existência ou a considerou na sua complexidade. Durante muito tempo, negou-se a existência das diferenças no processo pedagógico e essas foram percebidas como "desvio", tendo como referencial a dicotomia normalidade versus anormalidade, demarcando a existência de fronteiras entre aqueles que se encontravam dentro da média e os que estavam fora desta.

Identificada como uma das mais importantes marcas do pensamento moderno, a caracterização das diferenças como anormalidade constitui a negação das mesmas como uma primeira formação discursiva, a qual traz implícito o referencial de normalidade como parâmetro. O que está em jogo é, na verdade, a apologia do normal. A negação refere-se ao fato de não se trabalhar explicitamente a questão das diferenças. O que se busca é a compreensão de um universal calcado na essência da existência humana, no qual não são levadas em conta quaisquer características individuais e/ou grupais numa homogeneidade simplória e ideologicamente excludente. São os casos das filosofias e das pedagogias essencialistas, que falam de traços gerais e, por isso mesmo, de sentido único e universal, no dizer de Marques (2006).

Os nomeados como diferentes foram, assim, historicamente discriminados. Vítimas da rejeição e/ou da compaixão social, estes estiveram sempre à margem do convívio com os cidadãos considerados normais, sendo, inclusive, segregados, em muitos dos casos, em ambientes (instituições) restritivos, como são os casos dos asilos, escolas especiais, hospitais psiquiátricos etc. Cabia, também, à escola classificar e selecionar os sujeitos, isolando os que fugiam ao padrão construído socialmente.

$\mathrm{Na}$ formação, há que se interrogar essa concepção que nega as diferenças e trazer à tona a concepção de alteridade. $\mathrm{O}$ reconhecimento do outro como protagonista do teatro da vida constitui o vetor da mudança de paradigma. Consentir com a diferença é mais do que um simples ato de tolerância, é a afirmação de que a vida se amplia e se enriquece na 
multiplicidade. Ser diferente não significa mais ser o oposto do normal, mas apenas "ser diferente". Este é, com certeza, o dado inovador: o múltiplo como necessário, ou ainda, como o único universal possível. Para a existência não há dados especificantes: o outro é e ponto final. Não se coloca o outro como diferente, mas compreendemos as diferenças como formas concretas da existência, ou seja, como formas possíveis e dignas de se estar no mundo. (Marques e Marques 2006).

É, segundo Skliar (2006), a pedagogia de um outro tempo. Uma pedagogia que não pode "ordenar, nomear, definir, ou fazer congruentes os silêncios, os gestos, os olhares e as palavras do outro" (Skliar, 2006, p. 214). É a pedagogia que pretendemos, mas não sabemos fazer. É a pedagogia de experiências ricas, de cotidianos diversos, que empobrecemos na medida em que pesquisamos e tentamos traduzir em relatórios, utilizando, para tal, referenciais do discurso colonizador no qual estamos mergulhados.

$\mathrm{Na}$ formação, a problematização sobre as diferenças deve compor elemento fundamental, já que somos todos e todas diferentes. Na formação, os/as alunos/asprofessores/as têm a possibilidade de se abrir para buscarem em seu interior sua própria transformação, tornando-se mais críticos para o enfrentamento das situações-limites que lhes são impostas na escola e na sociedade.

O discurso veiculado por psicanalistas do campo Psicanálise e Educação reafirma a impossibilidade do ato de educar, objetivando desconstruir a racionalidade técnica imposta pela pedagogia, que, na busca incessante pela eficiência, acaba privilegiando as questões didático-metodológicas, suprimindo as questões relacionais (relação professor-aluno) do trabalho docente. Educar é tratar de uma "profissão impossível"3 e, consequentemente, de um sucesso insuficiente, já que é marcada pela presença do inconsciente. A educação de crianças não pode tratar esses (des)encontros apenas por meio de técnicas, pois, desse modo, acabaria caindo na armadilha da aplicação de regras e excluiria o lugar do aluno enquanto sujeito desejante. Desejo este que não cessa de não se inscrever. No ato de educar, o insucesso é constitutivo e a técnica não é garantia de nenhuma prática de êxito, já que as rupturas estão sempre se manifestando. Tendo esse cenário em vista, o professor não deve recuar frente a seu ofício, e sim esvaziar o lugar do ideal metodológico e da racionalidade técnica, aceitando o lugar da "contingência radical da experiência" (Pereira, 2012, p. 72).

Esse cenário demonstra a complexidade da profissão docente, começando pelo próprio enquadramento do que seja uma profissão relacional: só há professor/a quando há aluno/a. Dessa forma, o/a professor/a está cada vez mais longe de ser um técnico que desenvolve ou implementa inovações prescritas. A complexidade da docência aponta que não se pode pensar em educação sem considerar aspectos relacionais e afetivos, assumindo também que os processos de ensino e aprendizagem lidam com as incertezas, os conflitos e a possibilidade do fracasso. A partir da pluralidade de manifestações comportamentais, religiosas, políticas, sexuais, estéticas, de pensamento e inúmeras outras, os/as profissionais da educação têm se perguntado: o que fazer? Como agir em relação a essas diferenças? Como lidar com os diferentes sujeitos que manifestam e querem manifestar-se de formas variadas no tecido social e na escola (Diniz, 2011)? Para os formadores/as de futuros/as profissionais da educação, resta o desafio de pensar o que e como transmitir aos 
profissionais da educação, no sentido amplo do termo (educação entendida como transmissão às gerações presentes dos saberes acumulados pelas gerações anteriores). A começar pela formação inicial de sujeitos, em sua primeira infância, na qual as marcas simbólicas ganham expressiva importância, até, em inúmeros casos, quando se tornam formadores/as de adultos em sua formação profissional. Nosso interesse em interrogar a complexidade na educação e na formação docente se coloca na interface psicanálise e educação, ainda que enfrentando resistências no campo educacional, por reafirmar, como Freud (1937), que "educar é tarefa impossível”.

\section{Diversidade, diferença, inclusão, exclusão: rumo ao reconhecimento das diferenças}

Sabemos que pensar na e sobre a diversidade é pensar a relação entre o eu e o outro, pois, ao considerarmos o outro, o diferente, somos levados a pensar em nós mesmos, na nossa história, nos nossos valores. Pensar em diferenças significa estabelecer comparações nesse par de opostos: semelhanças e diferenças. Ao considerarmos alguém ou alguma coisa diferente, estamos sempre partindo de uma comparação. Para que essa comparação se efetive, é necessário que se estabeleça um tipo de padrão ou de norma vigente no nosso grupo cultural como ponto de referência. Pode ser um padrão de comportamento, de inteligência, de esperteza, de beleza, de cultura, de linguagem, de classe social, de raça, de gênero, de idade, de sexualidade, bem como de condição física e mental. E o que se observa, geralmente, é a tendência à padronização de um tipo ideal, provocando assim inúmeros mal-estares diante do desvio a esses padrões.

Há sem dúvida um deslocamento de sentido na direção da superação do modelo excludente de sociedade por um modelo fundado no reconhecimento e no respeito às diferenças. Nesse contexto, situa-se o confronto entre o discurso dominante da exclusão e aquele construído a partir da voz dos nomeados como diferentes e/ou das pessoas com eles envolvidas na luta pelo reconhecimento das diferenças como condição existencial possível. Tal formação ideológica tem seus pilares na organização e na ascensão dos movimentos sociais, cujas vozes procuram - ou pela denúncia das práticas discriminatórias ou pela reivindicação de igualdade social - dar visibilidade às diferenças e ocupar os espaços deixados pela ideologia dominante, fundadora do modelo social da exclusão, o que se dá tanto em relação ao espaço físico quanto em relação ao espaço discursivo.

O campo da psicanálise tem apontado a questão da diferença como foco dessa discussão, demarcando a distinção entre diversidade e diferença. A diversidade será referida quando se tratar das identidades forjadas em prol da construção de políticas públicas. Já a diferença aponta para a subjetividade pela via da constituição psíquica, portanto, inconsciente. A diferença é exatamente essa possibilidade de se perceber como sujeito singular, legitimando inclusive a singularidade do outro - dizemos aqui de sujeitos atravessados pela falta e pelo desejo, sujeitos da diferença. Birman (2002) escreve que a diferença se conjuga pela singularidade. 
Nas polêmicas que envolvem os conceitos de diversidade e diferença, e com a preocupação em diminuir os conflitos existentes principalmente no ambiente escolar, em julho de 2004, durante o Governo Lula, foi criada a Secretaria de Educação Continuada, Alfabetização, Diversidade e Inclusão (SECADI), com o objetivo de contribuir para a redução das desigualdades educacionais, para que os/as professores/as e demais profissionais da educação exercessem seu papel de agentes em prol do respeito, contribuindo para que a escola não seja um instrumento de reprodução de preconceitos, mas sim espaço de promoção e valorização das diversidades. E, assim, com políticas de fomento à formação das/os professoras/es para tal, a SECADI ofertava cursos, palestras, eventos, materiais com essa finalidade, tendo desaparecido do cenário no governo ilegítimo de Temer, em 2017. Ainda que existissem inúmeros cursos de formação, o que se observava, na prática, é que havia um recuo do corpo docente diante do que é diferente. Por qual motivo estaria ainda o/a professor/a despreparado/a para lidar com tais situações? Há nesse caminho uma lacuna que nos convoca a buscar novas explicações.

Nessa perspectiva, há que se constituir metodologias de formação que alcancem a subjetividade e o reconhecimento da alteridade: o método autobiográfico, com as narrativas de formação, e as histórias de vida, como movimento de investigação e formação no campo da educação, que objetiva compreender a vida, ou parte dela, como possibilidade para desvelar e retomar processos históricos e socioculturais vividos pelos sujeitos em diferentes contextos, vêm caminhando nessa direção, de acordo com Marques (2006). Para Nóvoa (1988, p. 116), “[...] as histórias de vida e o método (auto) biográfico integram-se no movimento atual que procura repensar as questões da formação [...]". Os autores dessa linha, de acordo com Marques (2006), defendem que, ao retomar suas histórias, as pessoas podem caminhar para a compreensão das aprendizagens que construímos ao longo da vida, das nossas experiências e de um processo de conhecimento de si e dos significados que atribuímos aos diferentes fenômenos que permeiam a vida. A palavra é proposta como estatuto da singularidade, da subjetividade e dos contextos dos sujeitos, sendo o/a professor/a quem aponta sempre o dizível.

Porém, esses métodos nem sempre levam em conta as fissuras inconscientes que perpassam os processos de formação docente. Oposta à universalização, a psicanálise vai em direção à posição singular de um sujeito que não só é falado, mas que pode tomar a palavra e falar. Diversos dispositivos metodológicos têm sido constituídos abarcando a perspectiva clínica na formação docente: o método clínico, os diários de bordo, os testemunhos, a confrontação e também a Conversação. O dispositivo da Conversação, de acordo com Miranda (2010), funciona como uma extensão do método de "associação livre" de Freud, técnica fundamental da psicanálise. O que um diz, em grupo, pode tocar o outro e produzir perspectivas inéditas. A construção de novos saberes, afirma Miranda, é o que confere à Conversação a possibilidade de intervir e provocar mudanças, além de possibilitar que se recolha ali material para análise. Falar, afirma Miller (2003), implica em abrir a possibilidade de circunscrever a experiência a partir daquilo que afeta e não a partir daquilo que um outro espera. Para Miller (2003), o que interessa não se resume ao que o sujeito 
pode falar sobre si, ao sentido que dá a seus atos e desejos, mas àquilo que lhe escapa e que se apresenta nos tropeços de sua fala, na hiância entre o que diz e o que quis dizer.

\section{A conversação como dispositivo de formação ética e estética em direção ao reconhecimento da alteridade}

A Conversação foi proposta por Jacques-Alain Miller como uma estratégia de trabalho para o CIEN ${ }^{4}$ - Centro Interdisciplinar sobre a Infância, que desenvolve trabalhos de aplicação da psicanálise a outros campos do saber. Este Centro ${ }^{5}$, ligado ao Instituto do Campo Freudiano de Paris, é uma instância internacional, fundada por ocasião do IX Encontro Internacional do Campo Freudiano, em Buenos Aires, em 1996.

Os profissionais que conduzem as conversações não necessitam ser psicanalistas, podem ser de qualquer profissão, porém, é necessário que seja alguém atravessado pela "experiência de palavra", alguém que tenha experimentado e seja sensível à discordância entre o que se diz - o enunciado - e o que se "quer" dizer (ou diz sem querer) - a enunciação. Não basta que seja alguém "bem informado" ou "benevolente", que "dá a palavra" às crianças e adolescentes, mas que suporte os pontos de não-saber, de suspensão ou falha no discurso daqueles que vêm à conversação.

Ela visa, como uma entrevista na clínica, não somente constatar, mas oferecer a palavra para que aquele que fala possa, ele mesmo, ser tocado pelos efeitos de seu dizer, ora apropriando-se dele, ora afastando-se, tomando distância da palavra do outro, ora localizando-se e posicionando-se de um novo modo frente ao seu dizer.

A Conversação, como dispositivo, quando questiona a posição do/a professor/a sobre a docência, pode e vai ao encontro de questões que remetem àquilo que é proposto pelo próprio método das narrativas. Importante ressaltar que, dessa forma, elas se encontram enquanto uma nova possibilidade de escuta a partir de uma perspectiva que é a da implicação no ato educativo e não a da culpabilização, levando em consideração o sujeito, o sujeito do inconsciente. Diniz (2005) fala da possibilidade, a partir da escuta psicanalítica inserida na pesquisa/intervenção, de penetrar em coisas concretas e ocultas por meio de elementos pouco notados ou despercebidos, trabalhando com indícios e as chamadas "zonas cegas", também nos processos de formação docente.

E o que fazer com a falta de espaço verificada nas escolas para discutir, refletir e trabalhar a subjetividade e a alteridade? Como considerar o mais além do conhecimento teórico e pensar propostas pedagógicas levando em conta a divisão dos sujeitos envolvidos? Seria possível formar educadores/as para lidar com a liquidez do processo de ensino e de aprendizagem? Seria possível ensinar sem que o sujeito se perca no cimento do chão social e escolar? Fica em nós a inquietação insistente de pensar os/as professores/as não só como reflexivos, multiplicadores, mas sim como mobilizadores - de si, dos outros, de um processo - com menos paralisação e mais mobilização desses sujeitos de peculiaridades sociais, históricas, afetivas e, também, inconscientes. 
Considerando que professores e professoras são sujeitos socioculturais e biográficos, com diferenciadas condições de trabalho e de clivagens de idade, gênero, classe, crenças, raças e etnias, suas experiências e sua formação se distinguem. O recorte de gênero evidencia essa mudança radicalmente devido às atribuições doméstico-familiares inerentes à condição feminina. Ainda nos dias de hoje as mulheres acumulam funções domésticas e de cuidados com filhos e familiares, além do trabalho fora de casa, nem sempre considerado profissional. Embora muitos direitos das mulheres tenham sido conquistados, as assimetrias permanecem, e não só porque se multiplicam as denúncias de violência contra as mulheres, mas justamente pelas denúncias não realizadas, as assimetrias toleradas, as humilhações caladas, as violências cotidianas silenciosamente aceitas, de acordo com Marques (2006). Parece persistir um mesmo obstáculo a ser superado: aquele que limita as mulheres às exigências do doméstico e do privado, seja pela força do sentimento maternal construído socialmente (o que se exterioriza em profissões consideradas femininas, que se aliam ao cuidado, como é o caso da docência), seja pela aceitação tolerante da desigualdade de gênero, seja pela força que se legitima num conhecimento intuitivo daquilo que seria um bem para o outro (maternagem), ainda com Marques (2006). Não é possível ignorar que esse é um problema social, relacionado com o lugar e as representações sobre a mulher ao longo da história e na estrutura socioeconômica e familiar, assim como cultural, relacionado com os valores e as atitudes predominantes quanto ao gênero.

O século XX foi considerado, dentre outros aspectos, como o século das conquistas das mulheres. Houve importantes mudanças no perfil e no lugar que passaram a ocupar na sociedade. As tendências de mudanças se estenderam à escolaridade, à participação na força de trabalho e às relações familiares, como enfraquecimento da autoridade patriarcal. Os movimentos feministas e a organização das mulheres questionaram e abalaram os padrões de relações sociais dominantes. No entanto, os projetos que visam os deslocamentos femininos não podem prescindir de estarem atentos a uma perspectiva crítica e emancipatória.

É nessa esteira que vimos acompanhando a profissão docente, como uma profissão majoritariamente feminina, que continua conciliando as questões da mulher (na sociedade e as questões subjetivas) à maternagem e à docência, ainda considerada uma semi-profissão sem prestígio social e econômico e com poucas exigências de uma formação qualificada para exercê-la. Ainda que as mulheres se dirijam aos cursos de formação disponíveis, em sua maioria no campo da pedagogia e das demais licenciaturas, constata-se uma baixa qualidade desses cursos, considerados de menor prestígio nas universidades e, mesmo nas ciências humanas, a formação para a docência ocupa posição desprestigiada. Além disso, é no campo da formação docente que se reitera toda a problemática de gênero com grande pregnância na tríade mãe-mulher-professora. Vários relatos de mulheres evidenciam que sua formação é feita nos intervalos e entrelinhas, entre uma tarefa doméstica e outra, entre uma demanda materna e outra, entre o deslocamento de um trabalho e outro.

Em nossa pesquisa local em Ouro Preto - MG, acerca da educação e da formação docente para a diversidade, diferença e inclusão, constatamos que a categoria gênero continua invisibilizada nas pesquisas, bem como em estudos que abordam a formação 
cultural de professores/as da educação básica. Nossa hipótese para a dificuldade das mulheres-professoras no trato com a questão com a diferença é que elas próprias, mulheresprofessoras, são invisíveis para si mesmas e para a educação. Como perceber o outro se não se percebem a si mesmas?

\section{Formação ética e estética de mulheres professoras: uma experiência}

Por meio do programa de pesquisa/extensão Caleidoscópio, o qual foi fundado em 2009, incorporando ações culturais e artísticas às ações de formação continuada na região dos Inconfidentes, trabalhamos com as docentes da educação básica e discentes do ensino superior, relacionando temas da subjetividade, da diferença, da diversidade e inclusão. Inicialmente, dentro do projeto "Luz, Câmera e educação" foram organizadas, ao longo dos últimos anos, sessões de cinema comentadas, a "formação ética e estética de mulheresprofessoras", bem como visitas a museus, e a contextualização de cada história de fundação dos mesmos, da cidade onde se localizam, agregando cultura e gastronomia local a cada visita. Na pesquisa desenvolvida ${ }^{6}$ detectamos o mal-estar docente na região de Santa Rita de Ouro Preto, com alto índice de adoecimento de mulheres-professoras nessa microregião. Com as Conversações trabalhamos o mal-estar docente, por meio de uma pesquisa/intervenção, já publicada, e projetos de caráter extensionista, melhorando a atuação das mulheres-professoras e produzindo índices de redução dos quadros de adoecimento. Iniciada pela interrogação sobre o que causa mal-estar no exercício da sua profissão, a nossa pesquisa-intervenção buscou a possibilidade de escutar a professora em um lugar diferenciado do que comumente ocupa no ambiente escolar - ela deixou de ser apenas a professora para se falar e se colocar também enquanto sujeito. Foram realizadas dez sessões de Conversação em uma frequência quinzenal. Falar, afirma Miller (2003), implica em abrir a possibilidade de circunscrever a experiência a partir daquilo que afeta e não a partir daquilo que um outro espera. Miranda (2010) coloca a Conversação como uma extensão do método de "associação livre" de Freud, técnica fundamental da psicanálise:

O que um diz, em grupo, pode tocar o outro e produzir perspectivas inéditas. A construção de novos saberes, afirma Miranda, é o que confere à Conversação a possibilidade de intervir e provocar mudanças, além de possibilitar que se recolha ali material para análise (Miranda, 2010, p. 146).

Trabalhamos com 21 mulheres, professoras da zona rural, atuando nos anos iniciais da educação básica $\left(1^{\circ}\right.$ ao $5^{\circ}$ ano) da rede municipal de ensino de Ouro Preto. A grande maioria é casada, mãe e responsável pelos serviços de suas casas. Essas professoras trabalham em uma única escola, o que aponta uma característica bastante peculiar nesse recorte: a frequência quase restrita à casa e à escola, uma relação estreita entre os/as filhos/as e os/as alunos/as, do público e do privado que se misturam, trazendo como efeito aos sujeitos pouca mobilidade. 
A partir desses resultados, surgiu a proposta de formular um projeto de extensão de formação continuada nomeado como "formação ética e estética de mulheres-professoras", a fim de produzir deslocamentos não só no espaço físico em que elas circulavam, mas também deslocamentos psíquicos, por meio do contato com a arte, a cultura e a história veiculadas em diversos museus brasileiros. As visitas guiadas aos museus brasileiros visaram também ampliar a formação docente para a diversidade e a inclusão da diferença, já que esse tema foi apontado pelas professoras como de difícil assimilação e compreensão. A continuidade do trabalho prevê que a formação ética, enquanto posição subjetiva diante da profissão docente, ganhará peso em torno de temas sobre a diversidade de gênero, raça e etnia, bem como em relação aos aspectos ambientais, econômicos e culturais que atingem a região. Além das Conversações, foram disponibilizados textos, artigos e livros que tratam sobre os museus visitados, subsidiando os itens que as professoras encontrariam durante as visitas: elementos artísticos e culturais dos museus. Após as visitas aos museus, as mulheres-professoras também discutiram e escreveram sobre suas experiências, a partir da metodologia do testemunho? ${ }^{7}$.

$\mathrm{Na}$ primeira etapa do trabalho tínhamos financiamento de um projeto da $\mathrm{SECADI}^{8}$, o que nos permitiu organizar e executar algumas viagens ${ }^{9}$. Nesse artigo nos será possível abordar apenas uma das visitas. Em 2010, fizemos a visita ao Museu de Artes e Ofícios de Belo Horizonte, privilegiando o terceiro andar do Museu, cujas obras retratam as profissões femininas. O que se destacou na Conversação é que as mulheres-professoras não perceberam no museu nenhuma alusão à profissão docente, o que as deixou bastante intrigada. Por que um Museu que retrata as profissões antigas não faz alusão à docência como profissão? Embora o Museu conte com um setor educativo, as professoras elocubraram acerca da desvalorização e invisibilidade da profissão, pelo fato de ser predominantemente feminina e tão pouco valorizada em nossa sociedade. No entanto, ao se depararem com uma foto de seu distrito em um lambe-lambe no Museu, esse encontro surpresa teve um efeito de valorização e contentamento por encontrarem ali, naquele espaço visitado por brasileiros/as e estrangeiros/as, uma foto de sua localidade, e consequentemente viram a valorização de uma profissão, que era a de fotógrafo. Na Conversação que sucedeu a viagem à Belo Horizonte, e ao Museu de Artes e Ofícios, passando por um restaurante de comida típica mineira e um tour pela Praça da Liberdade, também considerada circuito cultural de $\mathrm{BH}$, as mulheres-professoras destacaram essa ampliação de seus horizontes e a identificação com a guarda e conservação de objetos antigos, os quais, segundo elas, andavam jogados em seus quintais, sem nenhum cuidado e atenção. Mais tarde, em 2015, as mulheres-professoras criaram o Centro Cultural "Zé Trembeco", em Santa Rita de Ouro Preto, aglutinando objetos e peças antigas do pai de uma das professoras, que também deu nome ao Centro. A reflexão em torno da história das profissões, a percepção da ausência de representação sobre a profissão docente no Museu e a importância da preservação da memória facilitaram muito a adesão das mulheresprofessoras ao projeto e as escolhas dos sete museus que vistamos ao longo dos cinco anos que o projeto aconteceu. Também a questão da identidade das mulheres-professoras do 
ponto de vista étnico-racial foi retomada por nós em uma das visitas ao museu Afrobrasileiro em São Paulo, constatando que, para elas, a questão racial era imperceptível.

\section{Buscando concluir...}

Trabalhar a diversidade, a diferença e a inclusão, considerando a subjetividade e a alteridade, são questões de longa data e ainda hoje continuam sendo um entrave, um nó na rotina escolar, no manejo do ofício de educar, um desafio posto à formação inicial e continuada de professores/as, que se desvela em inúmeras queixas, adoecimento, absenteísmo, senão em um fenômeno conhecido como mal-estar docente.

O contexto sócio-político-econômico nos aponta a necessidade de ressignificar e democratizar a educação, rompendo com a ideia de empregabilidade derivada da visão mercantilizada da educação e, assim, considerar os processos subjetivos que permeiam o campo, fomentando novas práticas de formação docente com atenção para aspectos que contribuam especialmente para as ideias de autogestão da escola, cidadania, ou seja, do direito das pessoas participarem dos processos de decisão e de seu próprio processo de formação - é a lógica da implicação que mencionei acima e mais uma vez aponto como possibilidade no trajeto das construções em educação (Diniz, 2005). De acordo com a autora:

É necessário que permaneça viva e intensa a inquietação de interrogar os modos, os usos e os resultados da formação docente standart, de modo a ressignificar a educação, potencializando-a em seus aspectos subjetivos, políticos, cognitivos, sociais, afetivos - para que a diversidade e a diferença possam ter lugar. Lembrando que a diversidade começa com o olhar atento para as diferenças daqueles/as que são os dispositivos para a sua consolidação, para aqueles/as que, antes de professores/as, são sujeitos da diferença, com suas crenças e histórias, sua vida sexual, sua cor e seu gênero (Diniz, 2005, p. 240).

O/a professor/a pode até operar com as teorias acerca das políticas e das formações para a diversidade, porém, o que se torna impossível é dar conta da diferença - da sua e do outro. Voltamos ao que foi escrito por Birman (2002) para pensar aqui com ele que a ideia de alteridade se relaciona com a possibilidade de acolher a angústia emergida da onipotência narcísica de conhecer e controlar o objeto que se desfaz. Seria, segundo ele, essa angústia a via para o reconhecimento da incompletude e da finitude de ser e do outro, instalando a condição de alteridade - e a possibilidade da diferença.

Para a Psicanálise, um possível encontro, quando ocorre, faz-se na diferença e não na similitude, considerando a particularidade e a história de cada um/a. Dessa forma, na discussão que estou fazendo é fundamental que antes de ver uma deficiência e/ou necessidade específica que o sujeito apresente, ou alguma das especificidades de gênero, sexualidade, raça e etnia, consigamos perceber quem é o sujeito que apresenta tal 
característica e como ele lida com ela, considerando assim sua singularidade, sua história. Porém, os processos segregativos existem mesmo em uma escola que se nomeie inclusiva, aberta à diversidade, pois, se estamos no campo discursivo, é preciso considerar que o próprio discurso segrega o real.

Para Lacan (1992), na cultura contemporânea, os processos segregativos têm sido cada vez mais intensos e a diferença considerada, não raro, como um fator de afastamento dos sujeitos. Há de forma muito explícita uma pulverização dos laços sociais: se não é possível se fazer UM, na maior parte das vezes evita-se estar com o outro em sua singularidade. Para se pensar em inclusão e práticas educativas e formativas que acolham a diversidade, faz-se necessário reconhecer a importância de se reconhecer a diferença. Um laço social que se possa fazer deve levar em conta que podemos sim viver juntos, mas que, para tal, é necessário reconhecer cada um/a na relação, seja esta de professor/a-aluno/a, homem/mulher...

A busca por modelos de formação que rompam com o tecnicismo já comprovadamente ineficaz tem me impulsionado a aprofundar a busca em outros dispositivos de formação que alcancem o sujeito do inconsciente.

Dessa forma, ao operar com a Conversação, a aposta se faz no possível deslocamento do discurso docente fixado e arraigado, pensando, em especial, nos mecanismos possíveis de serem inventados, construídos e buscados por eles/as próprios/as, para que os/as professores/as possam se reposicionar diante da sua prática, da sua subjetividade, bem como diante das diferenças que os/as alunos/as apresentem. Um posicionamento capaz de refletir no processo de ensino e de aprendizagem, possível de amenizar, inclusive, as queixas relacionadas aos baixos índices de educação. Lembrando, com Diniz (2005), que há sempre um ponto onde o sujeito não encontra resposta, tanto em sua relação com o saber quanto em sua vida, e, dessa forma, faz-se necessário o caminho da invenção.

Neste contexto de mal-estar em que vivemos, a sensação de vazio, de falta, fixa-se como premissa e o sujeito fica sujeitado à necessidade de preencher os vazios. O consumismo, as tecnologias, o individualismo e o discurso da dissolução das diferenças surgem então como os grandes condicionantes da atualidade. Vivemos a aceleração da nossa vivência temporal e a perda do valor das experiências, das vivências, inclusive das vivências de dor e sofrimento que são cotidianamente burladas por fármacos da felicidade. São tantos estímulos protagonizados pela virtualidade que nossa memória fica evanescente.

Nosso projeto visa contrapor-se a essa avalanche de gadgets ofertados para tamponar esse vazio. Entre a proposta, a preparação para a visita, a visita em si ao museu escolhido coletivamente e o retorno, a Conversação sobre o que causou em cada uma a experiência tem sido possível devido às pausas entre um acontecimento e outro, um intervalo, um tempo de recordação, para então permitir a elaboração, seja por meio da palavra, seja por meio da escrita.

Para nós formadores/as também há um efeito que busca contornar e entender o lugar da formação continuada na docência contemporânea, em meio a tantas cobranças e exigências sobre o/a professor/a, que deve realizar uma atividade fragmentária, atuando simultaneamente e em frentes distintas: manter a disciplina e ser afetuoso; atender 
individualmente aos alunos/as e seus ritmos de aprendizagem e atender às exigências de avaliações externas e/ou dos sistemas escolares e/ou dos pais; passar por uma formação especializada e ter que atuar como um docente polivalente. Interrogamos as metodologias de formação docente standart e buscamos sustentar uma metodologia que considere a subjetividade, a diferença e a diversidade.

Precisamos de mudanças, mesmo paulatinamente. Visto que a alteridade constitui a subjetividade como resposta e responsabilidade pelo "outro", esse é um caminho para que a ação educativa não seja violenta (Hermann, 2010). Do mesmo modo, se toda a educação visa formar o/a educando/a para o pleno exercício de sua liberdade, no contexto da ética da alteridade aqui proposta, tal formação visa a construção de relações sociais mais justas e responsáveis com o "outro".

\section{Notas}

1. Um conjunto de documentos expressam as lutas e avanços do movimento inclusivo no Brasil e no mundo: a Declaração Mundial de Educação para Todos (1990), a Declaração de Salamanca (1994) e a Convenção Interamericana para a Eliminação de Todas as Formas de Discriminação contra a Pessoa Portadora de Deficiência (1999), bem como a Constituição Federal Brasileira (1988), a Lei Nacional de Diretrizes e Bases - LDB 9.394/96, a Política Nacional de Educação Especial e as Diretrizes Nacionais para a educação especial (2001). Esses documentos salientam a importância de se respeitar o sujeito na sua totalidade, considerando suas diferenças e potencialidades, objetivando, assim, assegurar ao mesmo o bem-estar físico e psíquico. Em 2008, começaram a ser implementadas as salas de recursos multifuncionais, com equipamentos que aumentam a oferta do atendimento especializado.

2. A teoria Charloteana, mesmo tendo como público das investigações os/as estudantes, remete explicitamente a estudos da relação com o saber sobre outros sujeitos, tais como o/a professor/a. Essa possibilidade justifica-se pela ideia do aprender como condição humana: como um ensinante/aprendente.

3. Freud, em 1937, no texto "Análise terminável e interminável”, a espelho do que introduzira em 1925, em "Prefácio à Juventude Desorientada, de Aichhorn", anuncia a existência de três profissões impossíveis: governar (política), educar (educação) e curar (psicanálise). O impossível de educar postulado por Freud nos leva a apostar que a educação está consolidada com base num insucesso constitutivo, pois sempre existirá a falta de êxito quanto aos objetivos alcançados. É preciso ter cuidado ao dizer que a educação tem em sua estrutura um insucesso constitutivo, pois isto vem sendo muito utilizado para justificar a falta de preparo e a desresponsabilização de professores/as em relação ao que acomete seus alunos/as. Concordar com o fracasso da educação seria um conformismo e Cifali (2009) vai então optar por usar a expressão "sucesso insuficiente". Tendo em vista o campo de pesquisa da educação, percebemos que se está sempre na busca por modos de maximizar os efeitos educativos sobre a criança (adolescente, jovem ou adulto) na direção em que se deseja.

4. MILLER, Judith. CIEN: apresentação por Judith Miller. Correio Express - Escola Brasileira de Psicanálise, Belo Horizonte, n. 1, p. 62-69, 2003.

5. Desde sua criação, o CIEN é coordenado por Judith Miller.

6. FERRAZ, Claudia Itaborahy; DINIZ, Margareth. Nem tão contemporânea assim: a mulher-professora e seus tropeços diante da diferença. São Paulo: Editora Paco, 2014.

7. Esse trabalho pode ser conferido na dissertação de Natália Goulart, orientada por Margareth Diniz: A escrita autoral de mulheres-professoras. Mestrado em Educação - UFOP (2017).

8. SECADI - Secretaria de Assuntos da Diversidade e inclusão, atualmente extinta.

9. Todo o conteúdo do projeto pode ser conferido na Revista do Programa Caleidoscópio (UFOP, 2019). 


\section{Referências}

ANDRÉ, Marli Elisa Dalmazo Afonso de. Dez anos de pesquisa sobre formação de professores. In: BARBOSA, Raquel Lazzari Leite (Org.). Formação de educadores: arte e técnicas, ciências e políticas. São Paulo: Edunesp, 2006. p. 605-616.

BIRMAN, Joel (Org.). Feminilidades. Rio de Janeiro: Contra Capa Livraria, 2002.

BRASIL. Constituição da República Federal do Brasil. Brasília. Senado Federal. Centro Gráfico. 1988.

BRASIL. Ministério da Educação Ministério da Educação. Plano Decenal de Educação para Todos. 1990

BRASIL. Ministério da Educação Ministério da Educação. Lei de Diretrizes e bases da educação nacional de 20 de dezembro de 1996. (9394/1996).

BRASIL. Decreto n.3956, de 08 de outubro de 2001. Promulga a Convenção Interamericana para eliminação de todas as formas de discriminação contra as pessoas portadoras de deficiência. Diário oficial da República Federativa do Brasil. Brasília, 09 de outubro de 2001.

BRASIL. Ministério da Educação. Secretaria de Educação Continuada, Alfabetização, Diversidade e Inclusão (SECADI), 2006.

BRASIL. Resolução CNE/CP no 1/2006, de 15 de maio de 2006. Institui Diretrizes Nacionais para o curso de graduação em Pedagogia, licenciatura. Disponível em http/bit.ly/2Ujw0j8. Acesso em: 12 de mar. 2019.

BRASIL. Ministério da Educação. Secretaria de Educação Especial. Política Nacional de Educação Especial na Perspectiva da Educação Inclusiva. Brasília: MEC/SEESP, 2008

BRASIL. Instituto Brasileiro de Geografia e Estatística. Censo Escolar. 2015.

CAMPOS, Roselane Fátima. Do professor reflexivo ao professor competente: os caminhos da reforma da educação de professores no Brasil. In: PACHECO, José Augusto; MORAES, Maria Célia Marcondes de; EVAngelista, Olinda (Orgs.). Formação de Professores: perspectivas educacionais e curriculares. Porto: Porto Edictora, 2003. p. 83-103.

CIFALI, Mireille. Ofício Impossível? Uma piada inesgotável. Educação em Revista, Belo Horizonte, v. 25, n. 1, p. 149-164, 2009.

CHARLOT, Bernard. Da Relação com o Saber: elementos para uma teoria. Tradução de Bruno Magne. Porto Alegre: Artes Médicas Sul, 2000.

CHARLOT, Bernard. Relação com o Saber, Formação dos Professores e Globalização: questões para a educação hoje. Porto Alegre: Artmed, 2005.

ClOTT, Yves. A Função Psicológica do Trabalho. Tradução de A. Sobral. Petrópolis: Vozes, 2006.

CORDE. Declaração de Salamanca e linhas de ação sobre necessidades educativas especiais. Brasília,1994.

DINIZ, Margareth. Inclusão de pessoas com deficiência e/ou necessidades específicas: avanços e desafios. Editora Autêntica. BH. 2012

DINIZ, Margareth. O método clínico na investigação da relação com o saber para quem ensina: a tensão entre conhecer e saber. Tese (Doutorado em Educação) - Faculdade de Educação, Universidade Federal de Minas Gerais, Belo Horizonte, 2005.

DINIZ, Margareth. Revista do Programa Caleidoscópio. Editora UFOP. Ouro Preto. ISBN 978-85-2880330-3. 2013.

EVANGELISTA, Olinda; SHIROMA, Eneida Oto. Um fantasma ronda o professor: a mística da competência. In: MORAES, Maria Célia Marcondes de (Org.). Iluminismo às avessas: produção de conhecimento e políticas de formação docente. Rio de Janeiro: DP\&A, 2004, p. 81-98. 
FERRAZ, Claudia Itaborahy e DINIZ, Margareth. Nem tão contemporânea assim: a mulher-professora e seus tropeços diante da diferença. São Paulo: Editora Paco, 2014.

FERRE, Nuria Pérez de Lara. Identidade, diferença e diversidade: manter viva a pergunta. In: LARROSA, Jorge; SKLIAR, Carlos (Orgs.). Habitantes de Babel: políticas e poéticas da diferença. Belo Horizonte: Autêntica, 2001. p. 195-214.

FLEURI, Reinaldo Matias. Intercultura e Educação. Revista Brasileira de Educação, Santa Catarina, n. 23, p. 16-35, 2003a.

FLEURI, Reinaldo Matias. Educação intercultural, gênero e movimentos sociais no Brasil. Educar, Curitiba, Especial, p. 121-136, 2003 b.

FLEURI, Reinaldo Matias. Políticas da Diferença: para além dos estereótipos na prática educacional. Educação \& Sociedade, Campinas, v. 27, n. 95, p. 495-520, mai./ago. 2006.

FREIRE, Paulo. Pedagogia da Autonomia: saberes necessários a prática pedagógica. São Paulo: Paz e Terra, 2002.

FREUD, S. (1937). Análise terminável e interminável. In: Edição Standard Brasileira das Obras Psicológicas Completas de Sigmund Freud. Rio de Janeiro: Imago, 1980d. Volume 23.

FREUD, Sigmund. (1925). Prefácio à Juventude Desorientada de Aichhorn. In: Edição Standard Brasileira das Obras Psicológicas Completas de Sigmund Freud. Rio de Janeiro: Imago, 1980b. Volume 19.

GATTI, Bernadete A. Análise das políticas públicas para formação continuada no Brasil na última década. Revista Brasileira de Educação, Rio de Janeiro, v. 13, n. 17, jan./abr. 2007.

HARDT, Lúcia Schneider. Formação de professores: as travessias do cuidar de si. In:

HERMANN, Nadja. Ética, estética e alteridade. Autocriação e horizonte comum: ensaios sobre educação ético-estético. Ijuí: Ed. Unijuí, 2010. p. 123-136.

HERMANN, Nadja. Ética e Educação: outra sensibilidade. $1^{\text {a }}$ ed. Autêntica, 2010.

LACAN, Jacques. O Seminário: livro 17: o avesso da psicanálise. Rio Janeiro: Zahar, 1992. Proferido em 1969-70.

LAPLANTINE, F. Aprender Antropologia. São Paulo: Editora Brasiliense, 2000.

LARROSA, Jorge. Notas sobre a experiência e o saber experiência. Revista Brasileira de Educação, Rio de Janeiro, n. 19, p. 20-28, 2002. Disponível em: <http://bit.ly/2WejLqo>. Acesso em: 15 fev. 2010.

LARROSA, Jorge. O enigma da infância ou o que vai do impossível ao verdadeiro. In: LARROSA, Jorge; FERRE, Nuria Pérez de Lara (Orgs.). Imagens do outro. Petrópolis: Vozes, 1998. p. 67-86.

MANTOAN, Maria Teresa Eglér. Inclusão escolar: O que é? Por que? Como fazer? São Paulo. Moderna, Coleção Cotidiano Escolar, 2003.

MANTOAN, Maria Teresa Eglér. Ser ou estar: eis a questão - Explicando o déficit intelectual. Rio de Janeiro: WVA, 2005.

MARCELO, Carlos. A identidade docente: constantes e desafios. Revista Brasileira de Pesquisa sobre Formação Docente, Belo Horizonte, v. 1, n. 1, p. 109-131, ago./dez. 2009.

MARQUES, Luciana Pacheco et al. Formação de professores(as) para a diversidade. In: CALDERANO, Maria da Assunção; LOPES, Paulo Roberto Curvelo (Orgs.). Formação de professores no mundo contemporâneo: desafios, experiências e perspectivas. Juiz de Fora: EDUFJF, 2006. p. 117-128.

MARQUES, Luciana Pacheco; MARQUES, Carlos Alberto. Do Universal ao Múltiplo: os caminhos da inclusão. In: LISITA, Verbena Moreira Soares de Sousa; PIMENTA, Selma Garrido. Didática e formação de professores: um estudo sobre as possibilidades da reflexão crítica. Tese (Doutorado em Educação) - Universidade de São Paulo, 2006.

MAZZOTTA, Marcos José da Silveira. Educação Especial no Brasil: História e políticas públicas. 5 ed. São Paulo: Cortez Editora, 2005. 
MILLER, Jacques Alain. O Percurso de Lacan. Rio de Janeiro: Zahar editor. 2002.

MILLER, Judith. CIEN: Apresentação por Judith Miller. Correio Express - Escola Brasileira de Psicanálise, Belo Horizonte, n. 1, p. 62-69. 2003.

MIRANDA, Margarete Parreira. $O$ mal-estar do professor em face da criança considerada problema. Belo Horizonte: FAE/UFMG, 2010.

NÓVOA, Antônio. Os professores e sua formação. Lisboa: Dom Quixote, 1992.

ONU - Organização das Nações Unidas. Declaração Universal dos Direitos do Homem. 1948.

SCOZ, Beatriz Judith Lima; CASTANHO, Marisa Irene Siqueira; TACCA, Maria Carmem Vilela Rosa. Ensino e aprendizagem: a subjetividade em foco. Porto Alegre: Editora Liber Livro, 2012.

SKLIAR, Carlos. A inclusão que é "nossa" e a diferença que é do "outro". In: RODRIGUES, David (Org.). Inclusão e educação: doze olhares sobre a educação inclusiva. São Paulo: Summus Editorial, 2006. p. 1534.

SKLIAR, Carlos. As perguntas sobre a questão da inclusão ou de como acabar de uma vez por todas com as velhas - e novas - fronteiras em educação. Pró-Posições, Campinas, v. 12, n. 2, p. 11-21, jul./nov. 2001.

UNESCO. Declaração Mundial de Educação para Todos: plano de ação para satisfazer as necessidades básicas de aprendizagem. Jomtien, Tailândia. (1990).

\section{Correspondência}

Margareth Diniz. Mestre e Doutora em Educação pela Universidade Federal de Minas Gerais, Psicanalista, Professora Associada II de Psicologia da UFOP, Coordenadora do Observatório de Pesquisa Educacional CAPES/FAPEMIG e Líder do Grupo de pesquisa Caleidoscópio - UFOP/CNPQ. Integrante da RIPPEP - Rede Internacional de Pesquisa em Psicanálise e Inclusão e da RUEPSY Rede Universitária Internacional de Estudos Psicanalíticos em Educação.

ORCID: 0000-0001-6852-5389.

E-mail: dinizmargareth@gmail.com

Texto publicado em Currículo sem Fronteiras com autorização da autora. 